\title{
Lipid, Lipoproteins, Total Antioxidant Status and Organ Changes in Rats Administered High Doses of Cadmium Chloride
}

\author{
M.J. Olisekodiaka ${ }^{a}$ C.A. Igbeneghu ${ }^{b}$ A.J. Onuegbu ${ }^{a}$ R. Oduru ${ }^{b}$ A.O. Lawal ${ }^{a}$ \\ ${ }^{a}$ Clinical Chemistry Unit and ${ }^{\mathrm{b}}$ Histopathology Unit, Department of Biomedical Sciences, College of Health Sciences, \\ Ladoke Akintola University of Technology, Ogbomoso, Nigeria
}

\section{Key Words}

Cadmium • Total antioxidant status · Lipid $\cdot$ Lipoproteins •

Dyslipidaemia

\begin{abstract}
Objective: To determine the possible association between cadmium (Cd) exposure and alterations in plasma lipid and lipoprotein levels and total antioxidant status (TAS) in rats. Materials and Method: Twenty male albino rats assigned to 2 groups of 10 rats each (test and control) were used for the study. Each test animal model was given $1.0 \mathrm{mg} \mathrm{CdCl} / \mathrm{kg}$ body weight, administered intraperitoneally for 4 weeks. Blood samples obtained from both groups at the beginning (baseline) and after 4 weeks of Cd exposure were analysed for triglycerides (TG), total cholesterol (TC), high-density lipoprotein cholesterol (HDLC), low-density lipoprotein cholesterol (LDLC), TAS and Cd. Kidney and liver sections from the rats were examined. Results: The plasma TG, TC and LDLC levels were significantly higher in exposed rats than controls ( $p<$ $0.0001, p<0.0001$ and $p<0.001$, respectively). Plasma HDLC was reduced in the exposed rats compared to controls $(0.41$ \pm 0.22 and $0.68 \pm 0.14 \mathrm{mmol} / \mathrm{l}$, respectively). Conclusion: The observed dyslipidaemia and decrease in TAS could be due to increased free radical production causing oxidative stress. Damage to liver and kidney sections in the exposed group suggests that $\mathrm{Cd}$ toxicity results in detrimental histological changes and may be implicated in the aetiology of cerebrovascular diseases.

Copyright $\odot 2011$ S. Karger AG, Basel
\end{abstract}

\section{Introduction}

A possible role for cadmium (Cd) toxicity in the pathogenesis of several diseases has been reported in the literature [1]. Cd is an extremely toxic metal and its major sources in humans are food, cigarette smoking and occupational exposure. Food is the major route of exposure to $\mathrm{Cd}$, particularly in the non-smoking population [2]. Estimates of Cd content in beverages and 78 food samples consumed in Nigeria [3] indicate that the concentrations for many foods were higher than those reported for most countries [4]. The highest average concentration of $\mathrm{Cd}$ $(0.375 \mathrm{mg} / \mathrm{kg})$ was reported in dairy products [5]. In the smoking population on the other hand, Friberg et al. [6] showed that a smoker of 20 cigarettes/day would increase his/her daily intake of Cd by $2-4 \mu \mathrm{g}$. Cd is widely used in industries for the production of nickel-Cd rechargeable batteries, pigments, plastics and other synthetic products. For the workers in these workplaces, inhalation of $\mathrm{Cd}$ fumes can result initially in metal fume fever but may progress to chemical pneumonitis, pulmonary oedema and eventually death [7]. Symptoms of acute Cd exposure can manifest as dysuria, polyuria, dyspnoea, chest pain, irritability, fatigue, headache and dizziness [8]. Environmental exposure to $\mathrm{Cd}$ may cause liver injury [9], kidney damage and tubular proteinuria [10], cancer in different organs [11], testicular injury in rats [12] and induce oxidative stress and membrane disturbances in the nerve system [13]. Hellström et al. [14] have shown that exposure to

\section{KARGER}

Fax +41613061234 E-Mail karger@karger.ch www.karger.com
M. Japhet Olisekodiaka

Clinical Chemistry Unit, Department of Biomedical Sciences

College of Health Sciences, Ladoke Akintola University of Technology

Ogbomoso (Nigeria)

Tel. +234 703308 2543,E-Mail edenjaph@yahoo.ca 
Table 1. Plasma lipid, lipoproteins, TAS and Cd in control and test groups at baseline

\begin{tabular}{llll}
\hline Parameter & $\begin{array}{l}\text { Control }(\mathrm{n}=10) \\
\text { mean } \pm \mathrm{SD}\end{array}$ & $\begin{array}{l}\text { Test }(\mathrm{n}=10) \\
\text { mean } \pm \mathrm{SD}\end{array}$ & $\mathrm{p}$ value \\
\hline $\mathrm{TC}, \mathrm{mmol} / \mathrm{l}$ & $1.30 \pm 0.14$ & $1.32 \pm 0.22$ & 0.15 \\
$\mathrm{TG}, \mathrm{mmol} / \mathrm{l}$ & $0.33 \pm 0.09$ & $0.41 \pm 0.78$ & 0.05 \\
$\mathrm{HDLC}, \mathrm{mmol} / \mathrm{l}$ & $0.74 \pm 0.12$ & $0.80 \pm 0.20$ & 0.25 \\
$\mathrm{LDLC}, \mathrm{mmol} / \mathrm{l}$ & $0.39 \pm 0.23$ & $0.36 \pm 0.17$ & 0.14 \\
$\mathrm{TAS}, \mathrm{mmol} / \mathrm{l}$ & $2.65 \pm 0.91$ & $2.40 \pm 1.11$ & 0.20 \\
$\mathrm{Cd}, \mu \mathrm{mol} / \mathrm{l}$ & $1.75 \pm 1.10$ & $1.25 \pm 0.75$ & 0.14 \\
\hline
\end{tabular}

occupational or a relatively low environmental level of $\mathrm{Cd}$ appears to be a determinant for the development of endstage renal disease. In addition, Shaikh et al. [10] have suggested that oxidative stress appears to play a major role in chronic Cd-induced hepatic and renal toxicity; however, the administration of antioxidants protected against $\mathrm{Cd}$ toxicity. Badisa et al. [11] suggested that $\mathrm{Cd}$ in the presence of hydrogen peroxide causes DNA damage probably by the formation of hydroxyl ions. Furthermore, Murugavel and Pari [15] reported a significant increase in plasma lipids, including total cholesterol (TC), low-density lipoproteincholesterol (LDLC), triglycerides (triacylglycerol, TG), free fatty acids and phospholipids following subcutaneous administration of $3.0 \mathrm{mg} \mathrm{Cd} / \mathrm{kg}$ body weight to rats for a period of 3 weeks. A significant reduction in high-density lipoprotein cholesterol (HDLC) level was also observed by the same author. Cd has been shown to deplete glutathione and protein-bound sulphhydryl groups leading to an enhanced free radical production, oxidative stress and detrimental effects such as peroxidation of lipids, proteins, carbohydrates and DNA molecules [11]. At present, single studies related to the effects of Cd on lipid, lipoproteins and total antioxidant status (TAS) appear sparse. The present study was therefore carried out to determine the possible association between $\mathrm{Cd}$ exposure and alterations in plasma lipid and lipoprotein levels and TAS in rats.

\section{Materials and Methods}

\section{Experimental Design}

Twenty adult male albino rats were obtained for the experiment. They were acclimatized for 2 weeks. Thereafter, the rats were randomly divided into two groups. Group 1 consisted of 10 rats and served as the Cd-exposed group, while group 2 that was also made up of 10 rats served as control. Each animal was assigned a separate cage, allowed free access to drinking water and was fed ad libitum with commercially available rat pellets.

\section{Protocol for Cd Administration}

At the end of the acclimatization, the animals in the test group were given $1.0 \mathrm{mg} / \mathrm{kg}$ body weight/day intraperitoneally while the control group continued with their normal diet and water without exposure to $\mathrm{Cd}$. Intraperitoneal injection was performed using a needle size/gauge of $25 \mathrm{~mm} / 23-27$ gauge after the rat had been restrained. The rat was slightly tilted so that its head was facing towards the floor to allow the abdominal organs to move toward the thoracic cavity while a second operator inserted the needle laterally to the midline, injecting into the lower squares of a quadrant drawn onto the rat's abdomen and thereby avoiding major organs. Administration of Cd lasted for a period of 4 weeks.

Blood Collection, Storage and Analysis

Blood samples were obtained from animals in the test and control groups at the commencement of the experiment. Whole blood $(2 \mathrm{ml})$ was obtained from each animal by tail bleeding after each animal had been anaesthetized with chloroform in a special chamber after 4 weeks of intraperitoneal injection of $\mathrm{CdCl}_{2}$. The animals were sacrificed by cardiac puncture and a second set of blood specimens was obtained from each rat. Blood samples were collected into tubes containing lithium heparin as anticoagulant and centrifuged at 3,500 rpm for $5 \mathrm{~min}$. The plasma was separated into a plain tube and stored at $-20^{\circ} \mathrm{C}$. TG and TC in plasma were determined using the enzymatic method of Buccolo and David [16] and Allain et al. [17], respectively, while HDLC was obtained after precipitation of other lipoprotein fractions [18]. LDLC was calculated using the formula of Friedewald et al. [19]. The TAS was determined using a spectrophotometric method described by Koracevic et al. [20] while the Cd level was estimated using an atomic absorption spectrophotometer [21]. Kidney and liver organs from rats in both the test and control groups were fixed in $10 \%$ formalin, processed and stained using the haematoxylin-eosin staining technique [22].

\section{Statistical Method}

Results were expressed as means \pm standard deviation. Pairwise comparison of means was made using the non-parametric $t$ test, and $\mathrm{p}<0.05$ was regarded as significant.

\section{Results}

At baseline, the mean TC, TG, LDLC, HDLC, TAS and $\mathrm{Cd}$ values of the control and test groups (table 1) were similar and the difference was not statistically significant ( $\mathrm{p}$ value ranged from 0.20 to 0.05 ). However, after 4 weeks, the mean values of TC $(1.08 \mathrm{mmol} / \mathrm{l}), \mathrm{TG}(0.28 \mathrm{mmol} / \mathrm{l})$ and LDLC $(0.36 \mathrm{mmol} / \mathrm{l})$ in the control group were significantly lower $(\mathrm{p}<0.0001, \mathrm{p}<0.0001$ and $\mathrm{p}<0.001$, respectively) than the corresponding values of the test group $(\mathrm{TC}=2.15 \mathrm{mmol} / \mathrm{l}, \mathrm{TG}=1.49 \mathrm{mmol} / \mathrm{l}$ and $\mathrm{LDLC}=$ $1.02 \mathrm{mmol} / \mathrm{l})$. The mean values of HDLC $(0.68 \mathrm{mmol} / \mathrm{l})$ and TAS $(2.37 \mathrm{mmol} / \mathrm{l})$ in the control group were however significantly higher $(\mathrm{p}<0.01)$ than those of the test group $(\mathrm{HDLC}=0.41 \mathrm{mmol} / \mathrm{l}$, TAS $=0.36 \mathrm{mmol} / \mathrm{l})$. Ex- 
pectedly, the mean plasma Cd level in the exposed group $(1.25 \pm 0.75$ to $5.96 \pm 1.23 \mu \mathrm{mol} / \mathrm{l}$ at 4 weeks after $\mathrm{Cd}$ treatment) increased significantly $(\mathrm{p}<0.001)$ from baseline after $\mathrm{Cd}$ administration for 4 weeks (table 2). Similarly, plasma TC $(2.15 \mathrm{mmol} / \mathrm{l})$, TG $(1.49 \mathrm{mmol} / \mathrm{l})$ and LDLC $(1.02 \mathrm{mmol} / \mathrm{l})$ were significantly higher $(\mathrm{p}<0.0001$, 0.0001 and 0.001 , respectively) after 4 weeks when compared with the corresponding baseline values $(\mathrm{TC}=1.32$ $\mathrm{mmol} / \mathrm{l}, \mathrm{TG}=0.41 \mathrm{mmol} / \mathrm{l}$ and $\mathrm{LDLC}=0.36 \mathrm{mmol} / \mathrm{l})$. HDLC and TAS values were significantly lower $(\mathrm{p}<0.01$ and 0.001 , respectively) following administration of $\mathrm{Cd}$ for 4 weeks (mean values $=0.80-0.41 \mathrm{mmol} / 1,2.40-0.36$ $\mathrm{mmol} / \mathrm{l}$, respectively) as given in figure 1 .

\section{Histology}

A kidney section from the exposed group was characterized by glomerular shrinkage, tubular necrosis and atrophy while the liver section showed congestion necrosis, fibrosis, collagen deposition and dystrophic changes.

\section{Discussion}

A significant decrease in TAS in rats exposed to $\mathrm{Cd}$ was observed when compared with the corresponding control. This observed decrease in the mean TAS of exposed animals could be due to the participation of the body's antioxidant system in combating the increased free radical load and probably the resultant oxidative stress created by the Cd toxicity in rats exposed to intraperitoneal injection of $\mathrm{Cd}$. A previous study [23] had shown an increased free radical load, increased level of peroxidation products and reduced level of glutathione in rabbit models after chronic exposure to $\mathrm{Cd}$. Antioxidants are known to prevent, protect and repair free-radical-mediated damage. Reports from Pari and Murugavel [13] suggest that diallyl tetrasulphide present in garlic attenuates the lipid peroxidation and alteration of antioxidant and membrane-bound enzymes in Cd-exposed rats, which suggests that diallyl tetrasulphide protects the brain function from toxic effects of Cd.

In the present study, significant increases in mean TC, TG and LDLC fractions were observed in Cd-exposed rats when compared with the respective means of the corresponding control group. Some studies involving the administration of $\mathrm{Cd}$ in animal models have demonstrated similar increases in TC, TG and LDLC fractions. Murugavel and Pari [15] showed that subcutaneous administration of $3 \mathrm{mg} / \mathrm{kg}$ body weight $\mathrm{Cd}$ to Wistar rats for 3 weeks resulted in significant increases in mean plasma

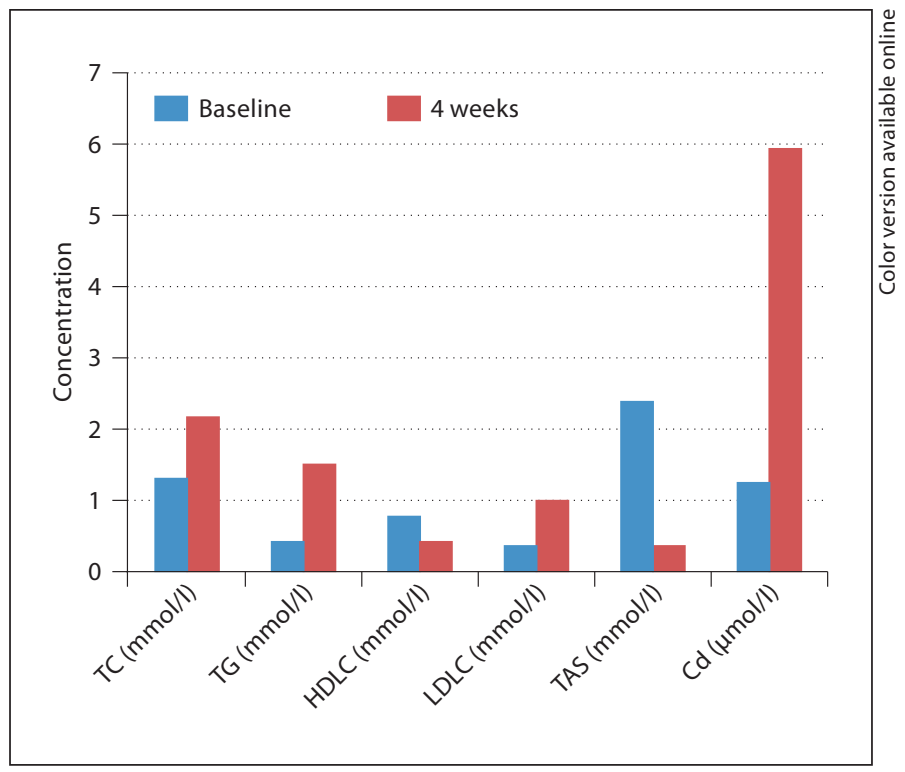

Fig. 1. Plasma lipid, lipoproteins, TAS and Cd in the test group at baseline and after 4 weeks of Cd administration.

Table 2. Plasma lipid, lipoproteins, TAS and Cd in control and test groups after 4 weeks of Cd administration

\begin{tabular}{llll}
\hline Parameter & $\begin{array}{l}\text { Control }(\mathrm{n}=10) \\
\text { mean } \pm \mathrm{SD}\end{array}$ & $\begin{array}{l}\text { Test }(\mathrm{n}=10) \\
\text { mean } \pm \mathrm{SD}\end{array}$ & p value \\
\hline TC, $\mathrm{mmol} / \mathrm{l}$ & $1.08 \pm 0.13$ & $2.15 \pm 0.34$ & 0.0001 \\
TG, $\mathrm{mmol} / \mathrm{l}$ & $0.28 \pm 0.07$ & $1.49 \pm 0.22$ & 0.0001 \\
$\mathrm{HDLC}, \mathrm{mmol} / \mathrm{l}$ & $0.68 \pm 0.14$ & $0.41 \pm 0.22$ & 0.01 \\
LDLC, $\mathrm{mmol} / \mathrm{l}$ & $0.36 \pm 0.31$ & $1.02 \pm 0.32$ & 0.001 \\
TAS, $\mathrm{mmol} / \mathrm{l}$ & $2.37 \pm 0.97$ & $0.36 \pm 0.33$ & 0.0001 \\
$\mathrm{Cd}, \mu \mathrm{mol} / \mathrm{l}$ & $1.75 \pm 1.10$ & $5.96 \pm 1.23$ & 0.0001
\end{tabular}

TC, TG, free fatty acids and phospholipids. A vast amount of evidence has confirmed that $\mathrm{Cd}$ exposure is associated with a number of distinct pathological changes including dyslipidaemia $[11,15]$. The mean plasma HDLC concentration was significantly higher $(\mathrm{p}<0.01)$ in control compared to the corresponding mean value in Cd-exposed animals in this study.

HDLC is usually referred to as the 'good cholesterol' because of its ability to drive the reverse cholesterol transport process which tends to extract excess cholesterol deposited in blood vessel walls and deliver it back to the liver for catabolism [24]. In general, Boisset et al. [25] suggested that liver diseases resulting from exposure to tox- 
ic Cd could reduce HDLC levels, cause dyslipidaemia and affect the beneficial functions of HDLC.

Stained histological sections of the liver in the present study showed that exposure of rats to $\mathrm{Cd}$ caused several notable histological changes such as congestion necrosis, fibrosis and dystrophy similar to the observations of Friberg [26] in the liver of rabbits administered subcutaneously with Cd. Tarasenko et al. [27] also reported dystrophic changes after intragastric administration of $\mathrm{Cd}$ while Shaikh et al. [10] observed amyloid deposition on liver cells exposed to $\mathrm{Cd}$.

The kidney section of rats in this study was characterized by glomerular shrinkage, tubular necrosis and atrophy similar to a decline in the glomerular filtration rate of rats treated parenterally with $\mathrm{CdCl}_{2}$ reported by Uriu et al. [28]. While prolonged exposure resulted in progressive sclerosis with impairment of glomerular filtration, Jarup et al. [8] also showed that changes as a result of Cd administration resulted in cellular atrophy, interstitial fibrosis and glomerular sclerosis.

\section{Conclusion}

This study confirmed previous findings that Cd can adversely affect lipid and lipoprotein profile via lipid peroxidation. Therefore, workers in occupations exposed to $\mathrm{Cd}$ should take adequate precautionary measures to minimize contact with such metals.

\section{References}

1 World Health Organization: Cadmium. The International Programme on Chemical Safety (IPCS) Monograph. Environmental Health Criteria No 134. Geneva, World Health Organization, 1992, pp 53-163.

2 Syers JK, Gochfeld M (eds): Environmental cadmium in the food chain: sources, pathways, and risks. Proceedings of the SCOPE Workshop, Brussels, Belgium, 13-16 September 2000. Brussels, Scientific Committee on Problems of the Environment, 2001, pp 1-8.

- 3 Onianwa PC, Adetola IG, Iwegbue CMA, Ojo MG, Tella OO: Trace heavy metals composition of some Nigerian beverages and food drinks. Food Chem 1999;66:275-279.

4 Egan K, Hamridge T, Kayama F: Cadmium - impact assessment of different maximum limits. Cadmium: WHO Food Additive Series. Geneva, WHO, 2005, vol 55, pp 35-46.

$\checkmark 5$ Onianwa PC, Lawal JA, Ogunkeye AA, Orejimi BM: Cadmium and nickel composition of Nigerian foods. J Food Com Anal 2000;13:961-969.

6 Friberg L, Kellstorm T, Nardberg GF: Cadmium; in Friberg L, Nordberg GF, Vouk V (eds): Handbook on the Toxicology of Metals, ed 2. Amsterdam, Elsevier Science Publishers, 1986, pp 37-43.

7 Nomiyama K: Experimental studies on animals: in vivo experiments; in Tsuchiya $\mathrm{K}$ (ed): Cadmium Studies in Japan. Amsterdam, Elsevier/North Holland, 1978, pp 47-86.

-8 Jarup K, Berglund M, Elinder C, Nordberg G, Vahter M: Health effects of cadmium exposure - a review of the literature and a risk estimate. Scand J Work Environ Health 1998;24:1-51.

$\checkmark 9$ Dudley RE, Svoboda DJ, Klaassen CO: Acute exposure to cadmium causes severe liver injury in rats. Toxicol Appl Pharmacol 1982;65: 302-313.
10 Shaikh ZA, Vu TT, Zaman K: Oxidative stress as a mechanism of chronic cadmiuminduced hepatotoxicity and renal toxicity and protection by antioxidants. Toxicol Appl Pharmacol 1999;154:256-263.

11 Badisa VL, Latinwo LM, Odewumi CO, Ikediobi CO, Badisa RB, Ayuk-Takem LT, Nwoga J, West J: Mechanism of DNA damage by cadmium and interplay of antioxidant enzymes and agents. Environ Toxicol 2007;22:144-151.

12 Kara H, Cevik A, Konar V, Dayangac A, Yilmaz M: Protective effects of antioxidants against cadmium-induced oxidative damage in rat testes. Biol Trace Elem Res 2007;120: 205-211

13 Pari L, Murugavel P: Diallyl tetrasulfide improves cadmium induced alterations of acetylcholinesterase, ATPases and oxidative stress in brain of rats. Toxicology 2007;234: 44-50.

14 Hellström L, Elinder CG, Dahlberg B, Lundberg M, Järup L, Persson B, Axelson O: Cadmium exposure and end-stage renal disease. Am J Kidney Dis 2001;38:1001-1008.

15 Murugavel P, Pari L: Diallyl tetrasulfide protects cadmium-induced alterations in lipids and plasma lipoproteins in rats. Nutr Res 2007;27:356-361.

16 Buccolo G, David H: Quantitative determination of serum triglycerides by the use of enzymes. Clin Chem 1973;19:476-482.

17 Allain CC, Poon LS, Chan CSG, Richmond W, Fu PC: Enzymatic determination of total serum cholesterol. Clin Chem 1974;20:470475.

18 Lopes-Virella MF, Stone P, Ellis S, Colwell JA: Cholesterol determination in high-density lipoproteins separated by three different methods. Clin Chem 1977;23:822-824.

19 Friedewald WT, Levy RI, Fredrickson DS: Estimation of the concentration of LDL cho- lesterol in plasma, without use of the preparative ultracentrifuge. Clin Chem 1972;18: 499-502.

20 Koracevic D, Koracevic G, Djordjevic V: Method for the measurement of antioxidant activity in human fluids. J Clin Pathol 2001; 54:356-361

21 Taddia M: Atomic absorption spectrophotometry of cadmium after solvent extraction with zinc dibenzyldithiocarbamate. Microchem J 1981;26:340-343.

22 Sood R: Textbook of Medical Laboratory Technology, ed 1. New Delhi, Brothers Medical Publishers, 2006, pp 1030-1047.

23 Pathak N, Khandelwal S: Role of oxidative stress and apoptosis in cadmium induced thymic atrophy and splenomegaly in mice. Toxicol Lett 2007;169:95-108.

24 Toth DF, Wonger H: Clinical Chemistry Textbook, ed 3. Oxford University Press, Oxford, 2003, p 423.

25 Boisset M, Girard F, Godin J, Boudene Cl: Cadmium content of lung, liver, and kidney in rats exposed to cadmium oxide fumes. Int Arch Occup Environ Health 1978;41:41-53.

26 Friberg L: Health hazards in the manufacture of alkaline accumulators with special reference to chronic cadmium poisoning: a clinical and experimental study. Acta Med Scand Suppl 1950;240:1-124.

-27 Tarasenko NY, Vorobjeva RS, Spiridinova VS, Sabalina LP: Experimental investigation of toxicity of cadmium and zinc caprylates. J Hyg Epidemiol Microbiol Immunol 1974; 18: 144-153.

28 Uriu K, Kaizu K, Komine N, Ikeda M, Qie YL, Hashimoto O, Matsuoka A, Eto S: Renal hemodynamics in rats with cadmium-induced nephropathy. Toxicol Appl Pharmacol 1998; 150:76-85. 